\title{
Confrontations Between Theists and Atheists
}

Verbal confrontations between believers and atheists ${ }^{1}$ are dangerous; they may lead to bloodshed, similar or worse than in the past, such as organized killing of clergy after the communist revolution in Russia, and the well-known slaughter of infidels and atheists by contemporary Muslim extremists. How to prevent this? One option is to promote the philosophical approach NOMA, formulated by the American scientist Stephen Jay Gould. ${ }^{2}$ The acronym NOMA stands for "Non-Overlapping Magisteria"; the phrase "non-overlapping" should be interpreted as differences in methods of investigation of our world. Referring to this approach, I wrote: "God is not a material entity, and attempts to refute God's existence by performing scientific experiments are not appropriate. Equally inappropriate are attempts to reject scientific claims, such as the age of the earth, on the basis of inconsistency with holy books". ${ }^{3}$

In "Bridging Science and Religion: Why It Must Be Done", Robert John Russell ${ }^{4}$ says that the path toward a world without aggressive confrontations is

\footnotetext{
${ }^{1}$ See Ludwik Kowalski, "Collected Internet Comments", http://pages.csam.montclair.edu/ kowalski/theo_sci.html (20.10.2014).

${ }^{2}$ See Stephen Jay Gould, (1997), "Non-Overlapping Magisteria”, Natural History 1997, vol. 106, pp. 16-22; Stephen Jay Gould, Rocks of Ages: Science and Religion in the Fullness of Life, Ballantine Books, New York 2002.

${ }^{3}$ See Ludwik Kowalski, "Futile Confrontations Between Theists and Atheists", American Atheist 2012, vol. 50, no. 1, pp. 28-29, 41, https://pl.scribd.com/doc/134940539/American-Athe ist-Magazine-First-Quarter-2012 (20.10.2014).

${ }^{4}$ See Robert John Russell, "Bridging Science and Religion: Why it Must be Done", http://www.ctns.org/about_history.html (20.10.2014).
} 
in cooperation between theologians and scientists. The NOMA approach can become the basis for such cooperation.

The first step toward mutual respect between theists and atheists should be the recognition that most people on earth are surrounded by material and spiritual realities. Scientific theories are accepted or rejected solely on the basis of laboratory work and observations of our material world. But intuition, inspiration, emotion and artistic satisfaction also play an important role in scientific research, especially at the earlier stages of investigation.

Traditional theological theories, on the other hand, are accepted or rejected solely on the basis of intuition and logical conformity with holy books. Some non-traditional theological interpretations will be mentioned below. A formal acceptance of NOMA, for example, by the Pontifical Academy of Sciences in the Vatican, would be a tremendously important step toward the elimination of dangerous conflicts. Will the acceptance of independence of science and theology be possible without significant changes in traditional interpretations of sacred books?

In the second chapter of his book ${ }^{5}$ Richard Dawkins wrote that "[...] miracle-free religion would not be recognized by practicing theists. What is the use of God who does no miracles and answers no prayers?" This is a good question. But one can believe in God without believing in miracles, as Spinoza did. His God was nature itself, not an entity outside of nature. The idea of an external God was formulated by humans. It evolved - and is still evolving — naturally. Referring to human history Dawkins names three kinds of religions: primitive, polytheistic and monotheistic. Why doesn't he recognize the existence of the fourth category - "miracle-free" religion? Because he probably thinks that an ideology without miracles is not a religion.

Such an attitude is debatable; several attempts to modify traditional Jewish theology are described by Rabbi Barry L. Schwartz. ${ }^{6}$ Most of them are still being debated. The famous theologian-reformer, Baruch Spinoza, excommuni-

\footnotetext{
${ }^{5}$ See Richard Dawkins, The God Delusion, Houghton Mifflin Company, Boston 2006.

${ }^{6}$ See Barry L. Schwartz, Judaism's Great Debates: Timeless Controversies from Abraham to Herzl, The Jewish Publication Society, Philadelphia 2012, Part 3: Modern Judaism.
} 
cated as a heretic by his contemporaries (in 17th century Holland), wrote: "By God's direction I mean the fixed and unchanging order of Nature [...] so it is the same thing whether we say that all things happen according to Nature's laws or that they are regulated by God's decree and direction".

Modern Reform Judaism is rooted in the nineteenth-century question - "is the Torah history or legend?" The German Rabbi Abraham Geiger asked: "How much longer can we continue this deceit [...] presenting stories from the Bible as if they were actual historical happenings?" He was probably referring to the story of the creation of the world in six days, the story of Jewish slaves in Egypt, etc. We respect such stories because they represent beliefs, and moral values, of our ancestors.

Addressing Geiger, another German rabbi, Samson Raphael Hirsch, asked, "Would you deny the Torah?" The answer was simple — "I do not deny the Torah. But [...] all laws and all prayers that are unworthy or irrelevant should be eliminated [from our books]". Why do some people think that only a small fraction of contemporary theologians would be willing to follow such advice? Because biblical stories are intertwined with recommended rules of morality. God, according to most clergy, records all our transgressions, and punishes those who disobey; many Christians believe in hell and heaven, and many Jews believe in exclusion and inclusion in the "world to come".

The famous scientist Albert Einstein wrote: "My views are near those of Spinoza: admiration for the beauty of and belief in the logical simplicity of the order which we can grasp humbly and only imperfectly [...]". 7 "I cannot conceive of a personal God who would directly influence the actions of individuals, or would directly sit in judgment on creatures of his own creation. [...] My religiosity consists in a humble admiration of the infinitely superior spirit that reveals itself in the little that we, with our weak and transitory understanding, can comprehend of reality. Morality is of the highest importance - but for us, not for God". ${ }^{8}$

\footnotetext{
${ }^{7}$ Walter Isaacson, Einstein: His Life and Universe, Simon and Schuster, New York 2008. Also in http://en.wikipedia.org/wiki/Religious_views_of_Albert_Einstein (20.10.2014).

${ }^{8}$ Helen Dukas, Albert Einstein: The Human Side, Princeton University Press, Princeton 1981, p. 66.
} 
Theology is like mathematics, not science. Mathematicians start with axioms (initially accepted truths) and use logical derivation to justify consecutive claims, called theorems. Once proven, a theorem cannot be rejected, unless a logical error is found in the derivation. Science is very different. Here, claims are justified, in the final analysis, by experimental observations, not by pure logic. A scientific claim becomes valid after it is confirmed in reproducible experiments. Furthermore, scientific validations are always tentative; scientists know that future experiments might result in rejection, or partial rejection, of what has already been accepted. Scientific truth is not claimed to be eternal.

There was an interesting article about Spinoza in "The Opinion Pages" section of The New York Times, written by a professor of philosophy, Steven Nadler; ${ }^{9}$ it generated many interesting online comments. A reader, RMC, wrote: "I know many Christians and Jews who practice their religious traditions although their own beliefs are secular. They make no secret of their sentiments. Spinoza was excommunicated during a time of religious orthodoxy and in that respect his experience is much like Galileo's. When the Catholic Church repudiated its treatment of Galileo, it was not merely saying that the earth revolves around the sun. It was saying that punishing the members of its congregation for thinking for themselves, including about church dogma, was parochial and destructive". With regard to independent thinking, several readers emphasized that traditional religious ceremonies, and respect for legends, do help to keep social groups together, even when people know that biblical legends do not represent historical truth.

Referring to the spiritual side of our existence, Rabbi Adin Steinsaltz ${ }^{10}$ wrote that it consists of "all things we relate to through our minds. This includes our thoughts and emotions, love, hate, and envy, the ability to read, to enjoy music, or to solve equations, to know that we exist, and relate to others. All of these are intangible - they cannot be touched or weighed. However, they are commonplace, direct experience, and they are as real as anything can be. All these together make up our second world, the spiritual one. [...] Is the spiritual world

\footnotetext{
${ }^{9}$ See Steven NAdLER, "Judging Spinoza", The New York Times 25 May 2014, http://opinionat or.blogs.nytimes.com/2014/05/25/judging-spinoza/?_php=true\&_type=blogs\&_r=0 (20.10.2014).

${ }^{10}$ See Adin Steinsaltz, Simple Words, Simon and Schuster, New York 1999.
} 
real? It is, in the same way that everything, which exists, is real. It cannot be touched, just as a scent or a magnetic field cannot be touched; it cannot be seen, just as the sound of a trumpet is invisible. Yet it can be perceived and measured".

The above comments are interesting. But what is the criterion for deciding what is material and what is spiritual? Yes, the magnetic field and the sound of a trumpet belong to the physical side of our existence, just as the emotional excitement caused by sound of a trumpet belongs to the spiritual side of that existence. Will it be possible to accept NOMA without a tool that allows us to objectively distinguish material from spiritual? Yes, everything that is touchable and visible belongs to our material world. But our reality is not limited to such things.

To understand different aspects of reality humans construct conceptual models, called theories. Predictions of solar eclipses, for example, are possible because we understand the solar system, using Newton's theory of universal gravitation. Theories are abstract logical structures. Both scientists and theologians use logic. Abstract concepts used by scientists and engineers, such as energy and temperature, are not material objects. How do they differ from abstract concepts used by theologians, such as God and soul? One difference is that scientific theories are quantitative while theological theories are qualitative.

The most important difference, however, is in something else. It has to do with ways in which theories are validated. Scientific theories are accepted or rejected on the basis of empirical data; theological theories, on the other hand, are usually accepted or rejected on the basis of intuition, and on the basis of logical consistency with holy books. The first approach is effective in investigations of material phenomena while the second is effective in investigations of spiritual phenomena. Will the NOMA philosophy help us to avoid real religious wars between theists and atheists? This will depend on the attitude of future generations toward that philosophy.

Addressing this issue - before the Pontifical Academy of Sciences, on November 10, 1979 - Pope John Paul II said: "The collaboration between religion and modern science is to the advantage of both, without violating their respective autonomy in any way. Just as religion demands religious freedom, so sci- 
ence rightly claims freedom of research". ${ }^{11} \mathrm{He}$ was referring to the deplorable case of Galileo Galilei, to whom freedom of conducting research was denied by Vatican theologians, in the 17 th century.

Ludwik Kowalski

\section{Confrontations Between Theists and Atheists}

\section{Summary}

The commentary focuses on Gould's idea of NOMA, according to which science and theology are two Non-Overlapping Magisteria. The term "non-overlapping" is appropriate because methods of validation of claims in these two fields of intellectual investigation. are different, not because the areas of investigation should be different.

The author was once an active atheist, in Poland; now he is a practicing theist, belonging to a Reform synagogue in the United States. He thinks that Gould's idea, if universally accepted, could help to reduce intensity of dangerous doctrinal confrontations between theists and atheists, and between different groups of theists. The commentary ends by a quote from a statement about desirable collaboration between religion and science, made by Pope John Paul.

Keywords: NOMA, Spinoza's God, theories in science, theories in theology, material reality, spiritual reality, Torah, Reform Judaism, biblical legends, miracles.

\footnotetext{
${ }^{11}$ John PAUL II, "Address to the Plenary Session (Commemoration of Albert Einstein) - 10 November 1979", in: Papal Addresses to the Pontifical Academy of Sciences 1917-2002 and to the Pontifical Academy of Social Sciences 1994-2002, Pontificiae Academiae Scientiarum Scripta Varia, vol. 100, Ex Aedibus Academicis In Civitate Vaticana 2003, p. 241 [239-244], http://www.casinapioiv.va/content/dam/accademia/pdf/sv100.pdf (20.10.2014).
} 